\section{The relationship between cadre's capacity and assessing to the fast food seller's per- formance in food hygiene and sanitation in Mokoau Primary Health Care, Kendari City}

\author{
Tasnim, ${ }^{1}$ Maria Inge Lusida ${ }^{2}$ \\ ${ }^{1}$ Sekolah Tinggi Ilmu Kesehatan \\ Mandala Waluya Kendari, Kendari; \\ ${ }^{2}$ Institute of Tropical Disease, \\ Universitas Airlangga, Surabaya, \\ Indonesia
}

\begin{abstract}
Kendari city had serious issues related to emerging a hundred of fast food sellers in 2017, including in Mokoau Health Centre area. However, there were only two health environmental staffs in that health care centre. Therefore, involving cadres in the fast food control become necessary. This study aimed to analyse the relationship between cadre's capacity and Assessing to the food seller's performance in food hygiene and sanitation management in Mokoau Health Centre in Kendari City since March 2019. There were 15 active cadres who controlled 35 fast food sellers. This study used the One-Group PretestPosttest Design. Data analysis used Paired T-test, Mann-Whitney test and Chi-Square test. This study found that $93.3 \%$ cadres had a senior high school diploma and only $6.7 \%$ of them had a Bachelor degree. There were $60.6 \%$ active cadres who had been in social health work for more than 5 years. The majority of cadres have got training about less than 15 times (86.7\%). Involving cadres in the fast food control affected to seller's performance change in fast food hygiene and sanitation management $(\mathrm{P}=0.006)$. Cadre with bachelor degree $(\mathrm{P}=0.006)$, were active in the social health work for less than 5 years $(\mathrm{P}=0.003)$, and got training less than 15 times $(\mathrm{P}-$ value $=0.026$ ) influenced significantly to cadre's assessing for the seller's performance in food hygiene and sanitation management. This study suggested that improving cadre's or community volunteer's knowledge and skill related to fast food control technique becomes necessarily diarrhoea was higher compared to other districts such as North Konawe (6.64\%) and Wakatobi $(15.87 \%) .{ }^{1}$ The uncontrolled fast food also have affected to non communicable diseases including hypertension. In 2015, the prevalent of hypertension was about $14.83 \%$. This was higher compared to $7.17 \%$ of Bau-Bau city. ${ }^{3}$

Therefore, the health department implement several programs to solve the problems, including collaboration between and within governments, food industries, nongovernment organization ${ }^{1}$. The local government also engages communities to control the food borne diseases. However, involving the community to control the fast food has been understood clearly. Besides that, there are only two health environmental workers in Mokoau Health care centre who have responsibility to supervise and control food traders. Therefore, involving volunteers from the community became important. However, the mechanism to involve them must be formulated, especially the capacity of the volunteers. This is because person who can control food must understand about food hygiene and sanitation management. Hence, the volunteer from communities shall have skill and knowledge related to that criteria. Therefore, the relationship between the capacity and ability to assess the fast food traders performance become this study question.

Based on that question, the aim of this study is to analyse the relationship between cadre's capacity and assessing the fast food seller's performance in food hygiene and sanitation management in Mokoau Health Centre in Kendari City.
\end{abstract} in fast food control.

\section{Introduction}

Fast food becomes one of the most public health important issues in Kendari City, including in Mokoau Health Care Centre. The number of the fast food trader increase every year. However, they become uncontrolled by Kendari City Health Department. In fact, in 2015, there were about 119 food traders, but there were only $65.79 \%$ that met with food hygiene and sanitation criteria. There were still $20.21 \%$ that did not meet with the criteria of hygiene and sanitation. ${ }^{1}$ This has increased the incidence of food poisoning. In 2016, the incidence of food poisoning become 2,869 cases compared to 814 cases in $2015 .^{2}$ Furthermore, increasing the number of uncontrolled fast food also affected to increase the incident of diarrhoea in Mokoau Health Centre in Kendari City (63.28\%). This incident of

\section{Materials and Methods}

This study was conducted in Mokoau Health Care Centre for seven months, from March to September 2019. There were 15
Correspondence: Tasnim, Sekolah Tinggi Ilmu Kesehatan Mandala Waluya Kendari, Jl.H.A.Nasution no.G-37 Kendari, Sulawesi Tenggara Indonesia.

E-mail: tasnim349@gmail.com

Tel.: +6282237658472

Key words: capacity, performance, fast food, control.

Contributions: $\mathrm{T}$ has contributed to carry on the research and write the the academic journal. MIL contributed to give suggestion regarding the methodologi of the research.

Conflict of Interests: The authors declare no potential conflict of interest.

Funding: This research was funded by the Ministry of Research, Technology and Higher Educaation of Republic of Indonesia in 20182019

Acknowledgements: We would like to thank to Ministry of Research, Technology and Higher Education of Republic of Indonesia in Financial support of this study and publication. Many thanks for our advised research, Prof. Dr.Maria Inge Lusida who supervised us to take this study. Our sincere also goes to director of College of Mandala Waluya Health Sciences Kendari who gave permission to take this study. For Head of Mokoau Health Centre and cadres. We would like to thank very much for your support and participation in this study.

Clinical trials: This study applied the quasy experimental study design.

Conference presentation: This result of this study was presented in the International conference on Infectious Diseases, Biothreats, and Military Medicine in Surabaya in 27-28 August 2019.

Received for publication: 17 February 2020. Accepted for publication: 1 July 2020.

This work is licensed under a Creative Commons Attribution-NonCommercial 4.0 International License (CC BY-NC 4.0).

${ }^{\circ}$ Copyright: the Author(s), 2020

Licensee PAGEPress, Italy

Infectious Disease Reports 2020; 12(s1):8765 doi:10.4081/idr.2020.8765

active cadres who controlled 35 fast food sellers. This Quasy experimental study used One-Group Pretest-Posttest Design. ${ }^{4}$ The sampling technique used the purposive sample with the inclusive criteria of sample were active cadre available in the village and there were many fast food traders surrounding their houses. The researcher 
excluded the communities who were no active in the social activity and there was no or limited the fast food traders surrounding their houses. The cadres were informally trained for two days about the principles of food hygiene and sanitation management, assessing method, and health promotion. They were also supervised and were given informal training for 3 months to increase knowledge and skill regarding to assessing and health promotion to sellers.

Independent variable of cadre's capacity was represented with educational level, duration of being social health workers, and the number of trainings. Dependent variable was assessing for fast food seller's performance in hygiene and sanitation management. There were category of scoring of the food seller's performance in Hygiene and Sanitation Management. The food seller's performance was categorized "Good", if the total score was more than 667 ( $\geq 667)$. The medium category of the seller's performance, if the total score was between 334-666. The seller's performance was categoried "Less", if the total score was under than 333 ( $\leq 333)$. Data was collected through scores which were collected by the 15 women volunteers with Observational sheets.

Data analysis used descriptive and inferential analyses. Descriptive analysis was to understanding percentage and distribution of the cadre's educational level, duration being social health workers and the number of trainings. Also, the distribution of fast food trader's performance related to their food hygiene and sanitation management. The inferential analysis was to understand the relationship between the cadre's capacity and assessing of the fast food trader's performance regarding food hygiene and sanitation management. The statistical analysis used Paired T-test, Mann-Whitney test and Chi-Square test.

\section{Results and Discussions}

This study recruited 35 fast food traders in Mokoau Health Care Centre area. Since March 2019, the 35s Fast food traders were supervised by 15 health cadres in that area. Each cadre supervised about 1-3 fast food traders based on the availability of the fast food traders and the distance between cadre's house and the location of fast food traders. There are many kind of fast food which are sold, such as: cake, fried banana, side of fish, meat, chicken, meat ball, yellow rice, saute vegetables, fried noodle and fried eggs.

The $15 \mathrm{~s}$ cadres have various capacity related to educational level, duration being social health workers and the number of trainings received. Detail of the cadre's capacity is presented in Table 1 below:

As presented at the Table 1, some of cadres who controlled the fast food sellers had a Senior high school diploma (93.3). There is only 1 of 15 cadres who had a Bachelor degree (6.7\%). People who have passed from Senior High School had enough knowledge and skill. Furthermore, on average the cadres have been involved in social health work in Mokoau areas for more than 5 years $(60.0 \%)$. There are small portion of them who became health cadres less than 4 years before $(40.0 \%)$. Table 2 describes cadres' training during her experience as a social worker. This means that the majority of cadres involved in the fast food control have had huge experiences in social health work. They are able to engage the community, related to communication and health knowledge.

Another indicator of cadre capacity is the number of training which have been given for cadres. Table 1 describes that the majority of cadres $(86.7 \%)$ have been trained less than 15 times. There was only small proportion of cadres who got training relating health knowledge more than 16 times $(13.3 \%)$.

Based on the Paired T-test, there was significant difference between the first assessing and the second assessing by cadres, $\mathrm{P}=0.006$ (Table 2 ). The result means that cadre involving can affect significantly to seller's performance in food hygiene and sanitation management. As presented in the below table, the performance of food sellers in hygiene and sanitation management was higher in the second assessing than the first assessing.

The seller's performance change was also associated significantly with cadre's educational status $(\mathrm{P}=0.006)$ (Table 3$)$. The highest educational level of cadres had higher average of seller's performance score difference than the senior high school level of cadres. This means that cadres who passed from bachelor degree have higher capacity of analysis of trader's performance change than cadres with senior high school level. As we know that educational institution of Bachelor's degree provide a curriculum which increases the undergraduate student's attitude, knowledge, general and specific skills, namely in the six level of Indonesia National Qualification Framework (INQF). ${ }^{5}$ The six level of INQF provide course works that give more analysis capacity for the undergraduate students. Therefore, this study has provided evidence from Implementation of Indonesia National Educational Policy. People with higher educational level also can be better at synthesize information and knowledge from difference sources. The curriculum of high educational institution is development to prepare bachelor students in adapted social activity, implementation of experience in cognitive, reproductive and creative activities and emotional and value attitude to the real activity in the community. ${ }^{6}$ In this study, cadres with a Bachelor's degree had

Table 1. Distribution of characteristic of cadre's capacity who involves in fast food control in Mokoau Health Care Centre Area in 2019.

\begin{tabular}{lcccc}
\hline Educational Level & $\mathrm{n} *$ & $\%$ & Mean & Standard Deviation \\
$\begin{array}{l}\text { Educational Level: } \\
\quad \text { Senior High School }\end{array}$ & 14 & 93.3 & 4.13 & 0.52 \\
$\quad$ Bachelor & 1 & 6.7 & & \\
$\quad \begin{array}{l}\text { Duration being the health Cadre: } \\
\quad<4 \text { Years }\end{array}$ & 6 & 40.0 & 9.13 & \\
$\quad>.5$ Years & 9 & 60.0 & & 8.75 \\
$\quad \begin{array}{l}\text { Number of Training: } \\
\quad<15 \text { times }\end{array}$ & 13 & 86.7 & 10.33 & \\
$\quad>16$ times & 2 & 13.3 & & \\
\hline
\end{tabular}

$\mathrm{n}^{*}=$ Number of sample.

Table 2. The difference of the seller's performance in food higiene and sanitation management between the first and the second assessing by cadres in Mokoau Health Care Centre in 2019.

\begin{tabular}{lcccccc}
$\begin{array}{l}\text { Seller's } \\
\text { Performance }\end{array}$ & $\mathrm{n}$ & Mean & $\begin{array}{c}\text { Standard } \\
\text { Deviation }\end{array}$ & \multicolumn{2}{c}{$\begin{array}{c}\text { Confidence } \\
95 \% \text { interval } \\
\text { Lower }\end{array}$} & Upper \\
The $1^{\text {st }}$ Assessing & 35 & 576.80 & 107.281 & -69.203 & -12.740 & 0.006 \\
The $2^{\text {nd }}$ Assessing & 35 & 617.77 & 83.892 & & & \\
\hline
\end{tabular}

*Paired t-test. 
better means to evaluate fast food traders in terms of personal communication.

Cadre's experiences in social activities, cant effect on the fast food trader's performance assessing $(\mathrm{P}=0.003)$ (Table 4). Cadres with social experiences inferior 4 year gave trader's performance assessing higher score on average (24.29) than cadres with more than 5 years in the social experience. People with more experience in the communities may have high expectation of fast food trader's performance in term of food hygiene and sanitation management. As we know that the role of the cadre is providing health education and connecting people with health care services. Therefore, they had rigid justification of assessing for fast food trader's performance. This will give beneficiary to the quality of sold fast food. This is because the cadres will have high motivation to give intensively health education to the fast food traders. Eventually, the condition will prevent the food borne diseases, including diarrhoea, typhus or hypertension of the chronic diseases. Furthermore, this study found that the number of training which was gotten cadres had significant association with assessing cadres to the fast food seller's perespecially in health program gave signifi-

formance in food hygiene and sanitation management $(\mathrm{P}=0.026)$ (Table 5). Primary health care centers or the local governments, including from village, sub district, district and provincial government provide training in the various knowledge. For health cadres, generally have been given training about general or special health knowledge, except the new cadres (less than 1 month). For example, environment cadres are given training about health environmental knowledge. This study was understood that cadres who got training less than 15 times increased the fast food seller's performance rate, compared to cadres with more than 16 times of training. The number of training is related to the duration of being active cadres in Mokoau Health Care Centre area. This means that the new cadres have ability to influence the traders in terms of food management behaviour. However, as described above that cadre who had huge experiences in the social activity gave rigid scoring of food seller's performance. Hence, cadres with more than 16 time of the number of training tended to reduce in the second assessing. However, the less proportion of those cadres did not mean that they could not change the fast food seller's behaviour in hygiene and sanitation

Table 3. The relationship between cadre's education and assessing the seller's performance in Mokoau Health Care Centre Area in 2019.

\begin{tabular}{llcccccc} 
No & Cadre' Education & n & $\%$ & Mean Rank & Sum of Ranks & Z* P value* \\
\hline 1 & Senior High school & 32 & 91.4 & 16.53 & 529.0 & -2.770 & 0.006 \\
2 & Bachelor & 3 & 8.6 & 33.67 & 101.0 & & \\
& Total & 35 & & & & & \\
& *Mann-Whitney U test.
\end{tabular}

Table 4. The relationship between duration of cadre in social activities and assessing the seller's performance in Mokoau Health Care Centre Area in 2019.

\begin{tabular}{llrrrrrr}
\hline No & $\begin{array}{l}\text { Duration of Cadre in } \\
\text { Social Activities }\end{array}$ & n & $\%$ & Mean Rank & Sum of Ranks & $Z^{*}$ & P value * \\
\hline 1 & $<4$ years & 14 & 40.0 & 24.29 & 340.0 & -2.964 & 0.003 \\
2 & $>5$ years & 21 & 60.0 & 13.81 & 290.0 & & \\
\hline & Total & 35 & 100.0 & & & & \\
\hline
\end{tabular}

*Mann-Whitney U test.

Table 5. The relationship between the number of training and assessing the seller's performance in Mokoau Health Care Centre Area in 2019.

\begin{tabular}{|c|c|c|c|c|c|c|c|}
\hline \multirow{3}{*}{$\begin{array}{l}\text { Number of } \\
\text { Training }\end{array}$} & \multicolumn{6}{|c|}{ The Difference of Trader's performance } & \multirow{3}{*}{$\begin{array}{l}\text { Fisher's } \\
\text { Exact Test* }\end{array}$} \\
\hline & \multicolumn{2}{|c|}{ Reduce } & \multicolumn{2}{|c|}{ Increase } & \multicolumn{2}{|c|}{ Total } & \\
\hline & n & $\%$ & $\mathrm{n}$ & $\%$ & n & $\%$ & \\
\hline$<15$ times & 3 & 10.0 & 27 & 90.0 & 30 & 100.0 & 0.026 \\
\hline$>16$ times & 3 & 60.0 & 2 & 40.0 & 5 & 100.0 & \\
\hline Total & 6 & 17.1 & 29 & 82.9 & 35 & 100.0 & \\
\hline
\end{tabular}

*Chi-square test. management. This is because of different expectation and perception of fast food seller's performance betwee less and more number of training.

\section{Conclusions}

The capacity of cadre who involved becomes important to make the right assessing for performance of the fast food sellers. Higher educational status of cadres who involve in the fast food control will give beneficiary to increasing the quality of fast food and seller's performance. The cadres who will be involved in this program are not necessary they must be active in social activity more than 4 years. They can be trained further to understand how they can assess rightly in term of fast food seller's performance of hygiene and sanitation management. The right assessing becomes very important to achieve the goal in this program. This program is expected to increase the quality of fast food hygiene and sanitation management. Eventually, this condition will reduce the food borne diseases, such as diarrhoea and typhus. Finally, the high quality of fast food consumed by communities will increase public health status in Mokoau Health Care Centre Area, especially.

This study was supported by other previous study which argued that the food sellert' behaviour became soo important to their sold clean and healthy fast food. ${ }^{8,9}$ Health promotion which was conducted by the Cadres to increase the food seller's knowledge about food hygiene and sanitation management become significant aspect to increase the quality of food. Increasing the seller's knowledge affected to their practices relating to food management. ${ }^{10,11}$ Good management of the food sellers affect significantly to reduce baterium of Escherichia coli. ${ }^{12-15}$ Increase the quality of food brings significantly to the seller's income because it increases costomer's satisfaction. ${ }^{16}$

Based on this finding, the health government, especially primary health care centres have responsibility to provide trainings to community volunteers or cadres. The special training of cadres can include the principle of food hygiene and sanitation management and technique of assessing the fast food trader's performance. Supervision of health environmental staff in Primary Health Care to cadres should be conducted to empower the cadres as a fast food controller.

\section{Implication for Public Health Policy and Programs}

This program should be included in the health program planning to solve the food 
borne diseases and chronic diseases related to food quality at the provincial level of Southeast Sulawesi especially. The program can be training for the cadres about the principle of food hygiene and sanitation management. A guide book for cadre about the principle of food hygiene and sanitation management must be provided. Furthermore, health promotion in the various types of media should also be implemented by health departments.

\section{References}

1. Health Department of Kendari City. Health profile of Kendari City in 2015. Kendari: Health Department of Southeast Sulawesi Province; 2016.

2. Bureau of Food and Drug Control. Annual Report of Bureau of Food and Drug Control in 2015. Jakarta: Bureau of food and Drug Control; 2016.

3. Health Department of South East Sulawesi Province. Health profile of Southeas Sulawesi Province in 2015. Kendari: Health Department of Southeast Sulawesi Province; 2016.

4. White H, Sabarwal S. Quasi-experimental design and methods. Florence, Italy: United Nations Children's Fund (UNICEF); 2014.

5. President of Republik Indonesia. President Regulation of Republic of Indonesia about Indonesia National Qualification Framework. Jakarta: Ministry of Human Right and Law of Republic of Indonesia; 2012.

6. Kutuev RA, Kudyasheva AN,
Buldakova NV, et al. Educaationalmethodical projects for students's intellectual competences formation: the imperative goal of the educational process of the university. Int J Environ Sci Educ 2016;11:7206-14.

7. Visker J, Rhodes D, Cox C. Community Health Workers in health-related Missouri Agencies: Role, professional development and health information needs. The Health Educator 2017;49(1):2-9.

8. Sari N, Marsaulina I, Chahaya I. Higiene sanitasi pengelolaan makanan dan perilaku penjamah makanan di kantin Sekolah Menengah Atas (SMA) Negeri dan Swasta di Kecamatan Rantau Utara Kabupaten Labuhan Batu Tahun 2012. Lingkungan \& Kesehatan Kerja 2013;2:1-10.

9. Hamzah MN, Narwati, Koemiasari. Perilaku penjaman makanan dalam menerapkan hygiene sanitasi makanan di Pondok Pesantran Darul Falah VKecamatan Diwek Kabupaten Jombang. Gema Kesehatan Lingkungan 2015;13:37-41.

10. Amalia IS, Rohaeni E, Muriawati D. Hubungan pengetahuan dan sikap dengan praktik hygiene sanitasi penjamah makanan di Kecamatan Kadugede Kabuapten Kuningan Tahun 2013. Jurnal Ilmu-Ilmu Kesehatan Bhakti Husada Kuningan 2015;4:52-7.

11. Miranti EA, Adin A.C. Hubungan pengetahuan dengan sikap dan higiene perorangan (personal hygiene) penjamah makanan pada penyelenggaraan makanan asrama putri. Media Gizi
Indonesia 2016;11:120-6.

12. Wardana AA, Gunawan AT, Hilal N. Hubungan hygiene sanitati makanan dan minuman terhadap kandungan bakteriologis Escherichia coli pada sop buah di wilayah Universitas Jenderal Soedirman, wilayah Gos Satria, dan wilayah Universitas Muhammadiyah Purwokerto Kabupaten Banyumas Tahun 2016. Buletin KeslingGMas 2017;36:262-8.

13. Sarldewi I, Pambudi A, Ningrum YF. Analisis bakteri Escherichia coli pada makanan siap saji di kantin Rumah Sakit X dan kantin Rumah Sakit Y. BIOMA 2016;12:21-34.

14. Azizah QN, Subagiyo A. Deskriptif hygiene sanitasi pengelolaan makanan di Lembaga Pemasyarakatan kelas IIB Kabupaten Cilacap Tahun 2017. Buletin Keslingmas 2018;37:405-534.

15. Nisa AK, Mawaddah. Hubungan hygiene sanitasi pengelolaan makanan dengan jumlah angka kuman pada mie ganyong yang diproduksi oleh home industry di Desa Majasari Kecamatan Bukateja Kabupaten Purbalingga. Keslingmas 2015;34:124-223.

16. Atmoko TPH. Peningkatan higiene sanitasi sebagai upaya menjaga kualitas makanan dan kepuasan pelanggan di Rumah Makan Dharma Palembang. Jurnal Khasanah Ilmu 2017;8:1-9. 